\title{
Comparison between China and the United States in Solar Energy Development
}

\author{
Jack Fuller ${ }^{1}$, Yang Guo ${ }^{1}$ \\ ${ }^{1}$ College of Business and Economics, West Virginia University, Morgantown, WV, USA \\ Correspondence: Jack Fuller, College of Business and Economics, West Virginia University, Morgantown, WV, 26506, \\ USA.
}

Received: July 9, 2016 Accepted: August 1, 2017 Online Published: August 4, 2017

doi:10.11114/set.v4i1.2578 URL: https://doi.org/10.11114/set.v4i1.2578

\begin{abstract}
The popularity and importance of solar power generation in the United States and China continues to increase. This research effort investigated the present status of solar power generation in both countries. The solar installation incentives provided by the two governments were analyzed. Comparisons between the countries would also focus on: (1) solar electricity generation capacity, (2) solar energy policy comparisons, (3) economic effects of solar energy development, and (4) future solar energy challenges. Conclusions would then be discussed on the comparison topics.
\end{abstract}

Keywords: renewable energy, solar energy generation capacity, solar energy policy, solar energy economic impacts, future solar energy challenges

\section{Introduction}

Renewable energy was the second largest source of global electricity generation in 2014 (International Energy Agency, 2015). Accounting for the negative influences caused by the combustion of fossil energy, more and more countries encourage their people to use renewable energy as an alternative way to support their energy needs. Solar energy is always recognized to be one of the best alternatives. However, it is still faced with challenges. Its resource (sunshine) is harmless, inexpensive, and continuously available. However, parts and equipment for capturing the sunshine and generating, transferring, and storing the solar electricity are expensive. Meanwhile, the development of the global solar energy market is still uneven. On the supply side, European countries were in first place in the production of solar PV panels prior to 2010. After 2015, first place was taken over by China. This country utilized lower production costs than other solar panel producing countries and produced 90 percent of the solar PV panels in the world. On the demand side, the United States and European countries represented the largest market for these solar PV panels (International Energy Agency, 2015). In combination, the industry was still promising for it created 2.8 million job opportunities in the world in 2015, which represented an 11 percent increase over the number in the previous year (International Renewable Energy Agency, 2016).

As the primary solar power generation application, solar PV systems became more and more developed through time. From 2000 to 2015, solar PV systems have improved their total generation capacity to finish in third place, after hydropower and wind power. The generation capacity of solar PV systems has skyrocketed from $1 \mathrm{GW}$ to $176 \mathrm{GW}$ during the same time interval (International Energy Agency, 2015). In the foreseeable future, the World Energy Outlook (2016) predicted that renewable energy would account for approximately two thirds of power generation in year 2040. Half of this would come from solar photovoltaic (PV) systems and wind (Internaltional Energy Agency, 2016). As a result, the sustainable growth of solar PV systems would account significantly for the world energy's safety and stability. Therefore, solar PV systems deserve closer attention, especially by countries who are very large energy consumers, such as the United States and China. Thus, the current research effort attempted to investigate the present status of the solar power generation industry in these two countries by making comparisons in various areas. This paper mainly focuses on the following four areas: (1) solar electricity generation capacity, (2) solar energy policy comparisons, (3) economic effects of solar energy development, and (4) future solar energy challenges.

\subsection{Comparison of Solar Electricity Generation Capacity between the United States and China}

Since the 1970's, the government of the United States has given significant support to solar energy development (Institute For Energy Research, 2016). Solar energy accounted for 29.5 percent of all new electricity generating capacity 
in the nation in 2015 (Solar Energy Industries Association, 2016). The total solar PV installed capacity was $18.5 \mathrm{GW}$ in 2014. Adding the installed capacity of $7.3 \mathrm{GW}$ in 2015 (Solar Energy Industries Association, 2016), the cumulative solar capacity reached $25.8 \mathrm{GW}$ at the end of 2015 (Forcast International's Energy Portal, 2016). It is estimated that cumulative solar capacity will grow to $59 \mathrm{GW}$ by the end of 2019 and to $100 \mathrm{GW}$ in 2040. The main increase will come from the utility solar market, accounting for about two thirds of the entire market (Solar Energy Industries Association, 2016). The amount of solar capacity in this sub-market reached $13.5 \mathrm{GW}$ in 2015 and is expected to reach $26.8 \mathrm{GM}$ in the next two years (U.S. Energy Information Administration, 2017).

In comparison, solar energy is the fastest growing renewable energy source in China, particularly after 2010. Following a 58\% annual growth rate, the total solar PV installed capacity grew from $0.86 \mathrm{GW}$ in 2010 (ChinaFAQs, 2014) to 50 GW in 2015 (ChinaFAQs, 2016) and is estimated to reach $114 \mathrm{GW}$ by the end of 2019. China installed $21.9 \mathrm{GW}$ of solar capacity in 2015 , making it the number one solar producing country in the world.

\subsection{Solar Energy Resources in the United States and China}

Solar PV systems generate electricity by capturing the energy in sunlight via solar panels. Both the United States and China have ample solar energy resources. According to the National Academies Press, the annual direct and diffuse solar radiation is 16 billion GWh (gigawatt hours) in the United States and 14 billion GWh in China, without taking into consideration conversion efficiency (National Academy of Engineering and National Research Council, 2010). Due to the uneven distribution of solar radiation within each country, certain areas are more suited to enjoying the benefits of abundant solar resources when generating solar electricity.

In the United States, the southwestern part of the country has the largest amount of solar resources, as estimated by the U.S. Department of Energy. Seven states (CA, NV, AZ, UT, NM, CO, TX) have the potential to generate more than $164 \mathrm{kWh} /$ year from one square foot of solar panel surface area. While states with moderate to low amounts of solar resources, such as New York and Massachusetts (energy.gov, 2016), do not have this advantage and cannot fully develop their state's solar energy without applicable financing options provided by state governments and local businesses.

In China, the Tibetan plateau region has the largest amount of annual direct solar radiation, $1,750 \mathrm{kWh} / \mathrm{m}^{2}(1,750$ kilowatt hours per square meter) per year. Provinces in the northwestern part of China, such as Xinjiang, Inner Mongolia, and Qinghai, also have ample solar radiation. Yunnan Province in the southwestern part of the country also has ample solar resources to develop a considerable amount of electricity from solar energy (National Academy of Engineering and National Research Council, 2010).

\section{Solar Energy Policy Comparison between the United States and China}

\subsection{Solar Energy Policies in the United States}

The federal government in the United States provides two primary policy supports to boost solar energy development: (1) Investment Tax Credits (ITC) and (2) Clean Power Plan (CPP). The amount of incentives was tailored for different types of users/investors. ITC is measured by the amount of investment in solar property. Solar power generation facilities constructed by the end of 2019 will get a 30 percent investment tax credit based on the total investment in facilities to reduce the same amount of their federal income tax payment. The rate will decrease to 26 percent in 2020 and 22 percent in 2021 and then to zero for residential and 10 percent for commercial and utility applications after 2023 (SEIA, 2016). The ITC helped develop Third Party Ownership, where residential and commercial users can enjoy the ITC with little or no down payment when using solar facilities installed by solar developers. The solar developers then retain ownership of the solar facilities and contract these facilities to users by charging appropriate fees. This type of third party ownership enables many people to generate solar energy with less financial burden and is one of the biggest drivers for solar energy development in the United States (Lowder, Schwabe, Zhou, \& Arent, 2015).

The final rule of the Clean Power Plan (CPP) was issued and became official on October 23, 2015, under the authority of the Clean Air Act. It influenced the solar industry by requiring states to reduce carbon emissions by 26 percent (based on 2005 's level) by 2020 and by 32 percent by 2030 . The way to realize this national goal was to adopt the Renewable Portfolio Standards (RPSs) at the state level. Each state has different renewable energy policies and emission reduction goals. A renewable portfolio standard (RPS) is a mandated regulation to increase production of energy from renewable resources, such as solar, by requiring a certain percentage of electricity to be generated from a particular technology, such as solar PV (Renewable Portfolio Standards, 2015). In the United States, 23 states and Washington, D.C., have an RPS with solar or distributed generation (DG) provisions (Zhou, 2015).

To build a healthy solar industry market, several state governments created tradable renewable energy certificates (RECs) for helping their electricity suppliers meet their RPS goals. Since the early investment in solar power generation facilities usually were higher than other types of renewable energies, such as wind and biomass, Solar Renewable Energy Certificates (SRECs) are typically priced higher than RECs from other renewable energy resources. Sixteen 
states and Washington, D.C., now have specific solar RPS provisions. These certificates are typically valued by market dynamics and purchased by electricity suppliers needing to meet their solar RPS requirements, with one SREC offsetting one megawatt-hour of solar electricity created (NREL, 2017).

Net metering is another means to help electricity suppliers meet their RPS goals. Residential and commercial users are encouraged to generate more solar electricity and reduce their electricity bills by selling any excess solar electricity back to the grid to have a smaller net metering electricity usage. Forty-four states, Washington D.C., and certain other areas have mandatory net metering rules. In 2015, over 2,100 megawatts (MW) of solar generation were added to the grid. This allowed utilities to benefit by creating more solar generation this way to meet their required solar RPS goals (National Conference of State Legislatures, 2016).

\subsection{The Solar Energy Policies in China}

Compared to the United States, China did not have renewable energy laws and regulations until 2005. At that time, the Chinese government passed the Renewable Energy Law to bring the development of renewable energy on track for the country's future energy stability and environmental protection. The Law was revised in 2009. After that, many supporting regulations were implemented with a goal to have 16 percent of their total electricity generated by renewable energy by the end of 2020 (NDRC People's Republic of China, 2007).

To benefit domestic consumers, the Chinese government issued several financial policies to make solar energy generated electricity affordable. The developers and investors in solar energy projects were provided with interest-free loans from government-owned banks. Residential users in certain provinces, who installed solar power systems in their households, would receive different amounts of subsidies, as determined by local authorities. Product subsidies have not been commonly applied in China in the past. In contrast to the United States, taxation exemption is not a common procedure in China. Several areas in the country have tax exemptions for imported solar facility construction materials and parts, such as PV panels (Song, Jiao, \& Fan, 2015). As an incentive, the government offered a 17 percent export tax rebate to help companies develop overseas (China Policy in Focus, 2016).

The two primary national solar subsidy programs in China were issued in 2009. The BIPV (Building-Integrated Photovoltaics) subsidy program focused on assisting with the development of roof-top solar PV facilities and providing construction material-based subsidies. Another program, the Golden Sun Demonstration Project, was to assist the solar PV industry in the nation by providing financial subsidies, not only for facility construction and usage, but also on technology improvement of solar facilities.

In 2013, the central government of Germany issued the solar PV industry Feed-in-tariff (FIT), which helped Germany expand its solar markets. This technique was then adopted by other European countries and China (Zhi, Sun, Li, Xu, \& $\mathrm{Su}, 2014)$. The FIT program has a duration of 20 years in China. The amount of tariff was determined by the appropriate authorities in consideration of the date of the completion of the projects, the condition of commercial operations, the cost of investment in technology and materials, and other factors. Any amount of tariff, exceeding traditional energy generated electricity prices, would be paid by the government from the Renewable Energy Development Fund. In late 2013, the Chinese government implemented the Chinese FIT Cross Control (CFCC) policy to reduce excessive financial burdens and test the stability of the domestic solar market. Under CFCC, only the amount of solar generation pre-arranged in line with the national goal (the maximum amount of solar power generated per year) would be subsidized. The excess amount over this goal would no longer receive a subsidy (Liu, Li, \& Zha, 2016).

\section{The Economic Effects of Solar Energy Development in China and the United States}

\subsection{The Economic Effects Brought by Solar Energy in the United States}

\subsubsection{Funding Resources}

On July 19, 2016, the Clean Energy Savings for All Initiative was launched in the United States with a mission of making solar energy affordable for every household. To develop a community solar initiative, the government put more effort into helping low-and moderate-income families use solar energy with a goal of adding one gigawatt (GW) of solar electricity in those households by 2020. A corresponding initiative, Solar Powering America, was intended to receive support from a variety of agencies to realize this goal as well as the President's Climate Action Plan goals. These goals included increasing by 100 megawatts the solar installations in federally-assisted housing. Research has shown that nearly 50 percent of consumers and businesses are unable to install PV systems due to a variety of reasons. A subprogram of Solar Powering America, the National Community Solar Partnership, can perhaps help those, who are not able to have their own PV system, to share a solar facility to allow them to have access to solar produced energy. The estimated investment in this program is from $\$ 8.2$ to $\$ 16.3$ billion by 2020 (Office of Energy Efficiency \& Renewable Energy, 2016). Agencies have developed different programs to fit different needs. For instance, the Weatherization Assistance Program (WAP) launched by the Department of Energy will contribute a maximum of \$3,545 per residence to offset utility bills for using solar electricity. The Department of Agriculture also implemented a 
program to help agricultural producers and rural small businesses use solar energy by providing grants to: (1) cover up to 25 percent of the eligible project costs or (2) guarantee loans to pay for up to 75 percent of the costs.

The SunShot Initiative, launched in 2011, was developed to facilitate the research and development of solar PV technology by providing various research program awards around the country. At the end of 2015, the target cost for utility-scale solar PV facilities, $\$ 0.06 / \mathrm{kWh}$, had been 70 percent accomplished. The SunShot National Laboratory Multiyear Partnership (SuNLaMP) funding program enabled scientists to conduct research in national laboratories to jointly advance solar PV technologies. Several small business voucher pilot projects were also available under this Initiative to test innovative research results (Office of Energy Efficiency \& Renewable Energy, 2016).

\subsubsection{Economic Achievements}

Solar energy does not only benefit the environment but also helps create job opportunities. The 2015 National Solar Job Census conducted by the Solar Foundation showed that almost 210,000 people were working in the solar industry as of November 2015, including 194,200 working in the solar PV industry. The results also indicated that the industry accounted for 1.2 percent of all jobs created in the country over the past year (The Solar Foundation, 2016). The Solar Energy Industry Association estimated that the number of employees working in this industry will double by the end of 2020 to 420,000 with an expected solar installation capacity of $100 \mathrm{GW}$ at the same time to create $\$ 140$ billion in economic contribution (SEIA, 2016).

\subsection{The Economic Effects of Solar Energy in China}

\subsubsection{Funding Resources}

The Chinese government invested $\$ 102.9$ billion in renewable energy development in 2015, 46 percent of which was invested in the solar energy industry (approximately $\$ 47.3$ billion). China's investment in its solar industry has surpassed its American counterpart's total amount of renewable energy investment of $\$ 44.1$ billion during the same period (ChinaFAQs, 2016). It can be estimated that the investment amount in its solar industry will keep increasing with the newly implemented 13th Five-Year Plan (2016-2020), which has a renewable energy target of 20 percent of the total energy generated by 2030 (Climate Nexus, 2015).

With a more developed domestic solar market, competition among Chinese companies is intense. The central government provides different kinds of subsidies or incentives to fund solar projects to benefit solar energy developers. Solar companies can get large amounts of low-interest loans from government-backed banks to finance expansion domestically or overseas. For example, two companies, Suntech and Trina Solar, jointly received $\$ 11.72$ billion from China Development Bank. Supported by beneficial land-use policies, these companies can also buy land at a below-market-average price to reduce production costs. Suntech and Trina acquired 3000 acres and 7000 acres of land awards, respectively (China Policy in Focus, 2016). Since 2009, the Ministry of Housing and Urban-Rural Development has tried to boost the development of building-integrated PV projects by subsidizing construction material-and-component-based projects by about $\$ 3 /$ watt and rooftop-and-wall-based projects by about $\$ 2.2 /$ watt. The 2010 Golden Sun Program was the second national subsidy program. The government promised to be responsible for 50 percent of the cost of solar power on-grid projects and 70 percent of off-grid projects. The amount of solar electricity generated beyond the developer's needs would be bought back by the electric grid companies, with on-grid tariffs similar to those set for coal-fired power generators.

\subsubsection{Economic Achievements}

China's renewable energy industry provided 3.5 million job opportunities in 2015, exceeding its traditional energy counterparts (1.7 million jobs were due to the solar PV industry, including 1.3 million in manufacturing, 330,000 in installation, and a small amount in other types). Though the solar PV market experienced a record high growth rate in 2015 , the employment rate in this industry showed a 2 percent decrease compared to the previous year. With the ambitious environmental goal set by the Chinese government, the solar industry is expected to grow more rapidly with $\$ 408$ billion value added to the whole industry by 2050 (Energy Research Institute, National Development and Reform Commission, 2015).

\section{Challenges in Developing Solar Energy in the United States and China}

\subsection{Common Challenges for Both Countries}

\subsubsection{Affordability}

Both countries need to tackle the problem of how to reduce the price of solar electricity to make it as affordable as traditional electricity. There are three things that might be obstacles to realizing this goal in the near future. First, the unequal distribution of solar radiation in both countries allows only certain parts of each country to take advantage of solar resources in an economical way. For instance, in the United States, several cities have realized an affordable price for solar electricity, compared to coal-generated electricity. Los Angeles currently lowers the cost for solar electricity to 
between $\$ 0.10$ and $\$ 0.15$ per kWh less than the cost of electricity from utility power (Los Angeles County Solar Map, 2009). However, solar electricity is still expensive for most people living in most of the country with average or poor solar resources. Second, the main subsidies for solar energy development are from the government. The government requires users to meet certain conditions to get the subsidies, making some people ineligible to receive solar subsidy benefits. In addition, these subsidies have a variety of loopholes and cannot cover all aspects of the solar market, limiting the price reduction scale of solar generated electricity. For example, considering the solar manufacturers in China, they are not given product subsidies. This means they cannot receive help from the Chinese government to increase their production lines to further lower their selling prices (Song, Jiao, \& Fan, 2015). Third, the government subsidies and incentives have made the governments themselves financially burdened, increasing the risk of cutting future money provided for this industry. Both the Investment Tax Credit (ITC) initiated in 2005 in the United States (Roselund, 2015) and the Feed-in-tariff (FIT) initiated in 2013 in China may be at risk (Liu, Li, \& Zha, 2016).

\subsubsection{Technique Bottlenecks}

The entire solar market is still looking for technology breakthroughs to improve the efficiency of solar electricity generation. The current technology for solar PV systems, using silicon cells to convert radiation to electricity, has an efficiency rate of 24.7 percent. More appropriate materials can be used to increase this rate. However, the unit production cost will increase due to better and more expensive materials being used (Hosenuzzaman, et al., 2015). Since the annual technology costs spent on improving the efficiency of PV systems may exceed the income generated from the annual installed PV systems (Santen \& Anadon, 2016), the result could be that the solar market becomes less attractive for investors. The solar industry may become stagnant due to a lack of research and development financial initiatives. Even though both governments provide funding for research purposes to enhance solar generation technologies, to implement the research results into the real world still takes time.

\subsubsection{Market Barriers}

Market barriers have limited the availability of less expensive materials for large-scale solar panel manufacturing. From a domestic viewpoint, various financing measures in each market segment benefit different users, making the development speeds varied in each segment. In the United States, the small commercial segment of the market cannot enjoy the benefits from the Investment Tax Credits system since their financial credit ratings are hard to count. There is a need to find new financing options to use solar energy facilities in an economical way without credit ratings (Office of Energy Efficiency \& Renewable Energy, 2016). In China, the unequal distribution of incentives has led to more serious problems. In some areas, low-quality projects were intended to be built in a larger scale to meet the standards for higher government incentives (Zhang, Deng, Margolis, \& Su, 2015). From a global perspective, Chinese companies are eager to sell more solar cells and solar facility parts to the United States to expand this market, while American companies are eager to buy more of these items from China due to their lower prices. Over 40 percent of solar panels manufactured by Chinese companies were for export purposes. Due to a large amount of government subsidies, the export prices of equipment and parts for solar power generation produced by Chinese companies are normally lower than the average price globally. This leads some countries, such as the United States (Bloomberg, 2015) and the European Union (European Commission, 2016), to levy anti-subsidy and anti-dumping taxation on such companies. The result is that Chinese companies cannot receive more profit by penetrating an international market and United States companies cannot achieve additional profit by lowering their production costs.

\subsection{Particular Challenges in the United States}

\subsubsection{Policy Loopholes}

Energy policy in the United States only sets a minimum goal of renewable energy in the whole energy mix. It does not set a maximum amount of electricity that certain types of renewable energy can generate, leading to deterioration of the energy efficiency in certain areas (Denholm, O'Connell, Brinkman, \& Jorgenson, 2015). For example, California now has a "solar over-generation" risk, which refers to the condition that the generation of conventional power cannot be cut further to offset the oversupply caused by the additional solar energy to achieve a balance of energy demand and supply in certain areas. Another problem relates to income tax credits. The 30 percent ITC usually cannot be used fully by smaller sized solar companies who do not have a large enough tax capacity to fully realize this benefit. Though the unused portion can be carried forward into later years, the value of the tax credit will depreciate due to the time value of money. Only large-sized companies can fully take advantage of this benefit, leading to unequal market competition.

\subsubsection{Policy Uncertainty}

The boom of the solar industry is due to preferential government policy supports, especially the 30 percent income tax credit (ITC). The expiration date of the ITC was extended several times, increasing the volatility of the installation capacity in different years. Investors would build more and larger solar facilities to benefit from last year's ITC, possibly causing a false solar popularity. Research has shown that if the ITC was not able to be extended successfully 
and let expire at the end of 2016, the installed solar capacity would experience a 71 percent drop in 2017. The current ITC extension to 2022 will smooth this "cliff" effect because of a more mature solar market, with an estimated 10 percent decline during the year 2022 (SEIA, 2016). Changes in political leaders also can have a great influence on solar energy development. The policy inconsistency between different policy regimes makes the future of the solar industry somewhat unpredictable.

\subsection{Particular Challenges in China}

\subsubsection{Lack of a Comprehensive Market Plan}

Though China's solar market has been developing for quite a long time, there is still no mechanism in place to make solar electricity tradable as the solar renewable energy certificates (SRECs) in the United States do. The Chinese government has realized this problem and has added a process for building such a market in its 13th FYP (2016-2020). At the end of 2017, China is going to have a nation-wide emission trading scheme (ETS), which will cap the amount of the carbon dioxide $(\mathrm{CO} 2)$ emissions and price the carbon allowances. The ETS will require the cooperation from businesses to record, report, and respond to their carbon emissions (United Nations Development Programme, 2016). Though the installed solar capacity in China was the largest in the world in 2015, its SRECs-like market scheme is still in its infancy, lagging the economic effects that the solar industry could bring to the business world.

\subsubsection{Anti-dumping Accusations}

Chinese companies have long struggled with anti-dumping problems in all industries, and solar is not immune to this issue. Back in 2009, China was sued by a German solar industry association for China's Golden Sun program, in which Chinese solar companies could get a 50 percent investment subsidy for solar power projects to cut their prices to be more competitive in the global market. A similar accusation occurred in Australia in the same year after Chinese companies lowered their exported solar panel price from $\$ 1600$ to $\$ 1050$ within a few months. On July 25,2014 , the United States Commerce Department imposed 165.05 percent anti-dumping duties on solar panels and cells from the Chinese mainland (Xie, 2014). Efforts to eliminate this exporting headache will be essential for China to expand its overseas solar market.

\subsubsection{Limitations of Distributed Generation Photovoltaic (DGPV) Projects}

The DGPV projects in China face primarily three obstacles. First, the size of a DGPV project is too large to be self-funded but too small to attract large capital investors. This embarrassing situation makes it hard to find a suitable way to finance their development. Second, residential buildings in China are more "high-rise" in style, instead of two or three levels. This makes it difficult to have a sufficient amount of roof-top PV facilities relative to its population size. The ownership of roof tops and land must be verified before implementing a DGPV residential project. In a commercial project, it is unlikely that business owners can use a solar project as collateral to obtain bank loans since the ownership of the business could change several times during the life of the solar project. If a commercial business goes bankrupt during the duration of the loan, the financing cost of the DG project could be very high. Third, DGPV systems tend to gradually connect to the state grid in recent years to improve the overall energy efficiency in China. The process of grid-connection is a big challenge for the Chinese government. Though the current process saves time and money, the high investment needed for DGPV projects requires the government to provide enough compensation and sharing measures for these project users and developers after grid-connection (Zhao, Zeng, \& Zhao, 2015).

\section{Conclusions}

\subsection{An Overview of the Comparison between China and the United States in Solar Energy Development}

The solar industry has progressed rapidly in the United States and China in recent decades. The comparisons made above were to let both countries learn from each other. This hopefully will allow them to cooperate with each other more closely and build a more established solar energy market in a global context. Both countries have their own limitations and strengths on the development of this industry. Though China has the largest installed solar capacity and is the largest exporter of solar panels in the world, the United States has established an advanced solar market, where regulations and trading tools were comprehensive and efficient. For China, the government agencies and business organizations should learn to build a healthier atmosphere for solar energy development by introducing what their American counterparts did successfully. For the United States, a more affordable supply chain of solar generation parts and equipment could be created by making trading agreements and encouraging business-to-business cooperation between the two countries. In addition to complementing each other's advantages, they could also work together to tackle their shared problems. To date both countries have not able to provide affordable solar power nation-wide. The solar industry could not support itself to date without the financial supports from their respective governments. This problem could possibly be resolved by additional technology breakthroughs to improve solar power generation efficiency. The United States and China should bring their engineers and scientists together in a cooperative manner to make this possible. 


\subsection{The Prospectus of Solar Energy Development in China and the United States}

The prospects for the solar energy industry in both countries will be determined by various factors. The solar industry could be influenced heavily by policy instability in the United States. With the successful extension of the 30 percent ITC, the solar market could keep progressing and be self-sufficient before the ITC expires in 2022. This is somewhat contingent on a continuing impetus to move from conventional energy resources to renewable energy sources by the new presidential team in 2017. A less developed market mechanism could hurt the growth of the solar industry in China. An excess amount of solar power generation was discouraged by the government due to financial reasons. The Chinese FIT by Cross Control (CFCC) policy set a cap for the amount of solar power that can be subsidized annually. This "solar cap" may have a negative effect on further solar facility promotion within the country. However, the lack of trading mechanisms in the market makes it difficult for facilities generating excess solar power to be financially benefited beyond that provided through government support. It was reported that Chinese PV module suppliers would be selling at a net loss with the current price in the first half of 2016. It is suggested that the government should investigate means to address this situation to keep the solar industry profitable and healthy in the future (Whitlock, 2016).

\section{References}

American Boiler Manufacturers Association. (2015). Determining \& Testing Boiler Efficiency For Commercial/Institutional Packaged Boilers. American Boiler Manufacturers Association. Retrieved from http://www.abma.com/assets/docs/Tech_Resources/2015\%20-\%20commercial_boiler_efficiency.determine.test_20 08.pdf

Bloomberg. (2015, July 9). U.S. Revises Tariffs and Duties on Chinese Solar Imports. Retrieved from Bloomberg: https://www.bloomberg.com/news/articles/2015-07-09/u-s-imposes-dumping-duties-on-imports-of-chinese-solar-g oods

China Policy in Focus. (2016, November 15). China's Solar Industry. Retrieved from China Policy in Focus: https://sites.google.com/site/chinapolicyinfocus/china-s-solar-subsidy-programs/china-s-solar-industry

China Policy in Focus. (2016, November 15). Other Forms of Government Support. Retrieved from China Policy in Focus:

https://sites.google.com/site/chinapolicyinfocus/china-s-solar-subsidy-programs/other-forms-of-government-suppo $\mathrm{rt}$

ChinaFAQs. (2014, May 22). Table: What Are China's National Climate and Energy Targets? Retrieved from ChinaFAQs: http://www.chinafaqs.org/files/chinainfo/ChinaFAQs_table_China_climate_energy_targets_0.pdf

ChinaFAQs. (2016, May 27). Renewable Energy In China: A Graphical Overview of 2015. Retrieved from ChinaFAQs: http://www.chinafaqs.org/files/chinainfo/ChinaFAQs_Renewable_Energy_Graphical_Overview_of_2015.pdf

Climate Nexus. (2015). China's Climate and Energy Policy. Retrieved from climatenexus.org: http://climatenexus.org/learn/international-actions/chinas-climate-and-energy-policy

Denholm, P., O'Connell, M., Brinkman, G., \& Jorgenson, J. (2015). Overgeneration from solar energy in California: a field guide to the duck chart. National Renewable Energy Laboratory. https://doi.org/10.2172/1226167

Energy Research Institute, National Development and Reform Commission. (2015, April). China 2050 High Renewable Energy Penetration Scenario and Roadmap Study (executive summary). Retrieved from http://www.efchina.org/Attachments/Report/report-20150420/China-2050-High-Renewable-Energy-Penetration-Sc enario-and-Roadmap-Study-Executive-Summary.pdf

energy.gov. (2016, October 7). Solar Energy Potential. Retrieved from energy.gov: https://energy.gov/maps/solar-energy-potential

European Commission. (2016). The European Union's Measures Against Dumped And Subsidized Imports Of Solar Panels From China. EU Trade Policy.

Forcast International's Energy Portal. (2016, November 15). Forcast International's Energy Portal. Retrieved from fi-powerweb.com: http://www.fi-powerweb.com/Renewable-Energy.html

Hosenuzzaman, M., Rahim, N., Selvaraj, J., Hasanuzzaman, M., Malek, A., \& Nahar, A. (2015, January). Global prospects, progress, policies, and environmental impact of solar photovoltaic power generation. Renewable and Sustainable Energy Reviews, 284-297. https://doi.org/10.1016/j.rser.2014.08.046

Institute For Energy Research. (2016, February 18). History of Solar. Retrieved from Institute For Energy Research: http://instituteforenergyresearch.org/analysis/history-of-solar-power/\#_ftn1 
Internaltional Energy Agency. (2016). World Energy Outlook (2016). Internaltional Energy Agency.

International Energy Agency. (2015). World Energy Outlook 2015. International Energy Agency.

International Renewable Energy Agency. (2016). Renewable Energy and Jobs - Annual Review 2016. IRENA.

Liu, C., Li, N., \& Zha, D. (2016, August). On the impact of FIT policies on renewable energy investment: Based on the solar power support policies in China's power market. Renewable Energy, 251-267.

https://doi.org/10.1016/j.renene.2016.03.033

Los Angeles County Solar Map. (2009). Los Angeles County Solar Map. Retrieved from Los Angeles County Department of Regional Planning: http://planning.lacounty.gov/solar/

Lowder, T., Schwabe, P., Zhou, E., \& Arent, D. J. (2015). Historical and Current U.S. Strategies for Boosting Distributed Generation. National Renewable Energy Laboratory. https://doi.org/10.2172/1233464

National Academy of Engineering and National Research Council. (2010). The Power of Renewables: Opportunities and Challenges for China and the United States. Washington, DC: The National Academies Press.

National Conference of State Legislatures. (2016, November 3). State Net Metering Policies. Retrieved from National Conference of State Legislatures:

http://www.ncsl.org/research/energy/net-metering-policy-overview-and-state-legislative-updates.aspx

NDRC People's Republic of China . (2007). Medium and Long-term Development Plan for Renewable Energy in China. National Development and Reform Commission People's Republic of China .

NREL. (2017, April 4). Voluntary Green Power Procurement. Retrieved from National Renewable Energy Laboratory: http://www.nrel.gov/analysis/green-power.html?page=5

Office of Energy Efficiency \& Renewable Energy. (2016, November 11). National Community Solar Partnership. Retrieved from energy.gov: https://energy.gov/eere/solarpoweringamerica/national-community-solar-partnership

Office of Energy Efficiency \& Renewable Energy. (2016, November 11). Photovoltaics. Retrieved from energy.gov: https://energy.gov/eere/sunshot/photovoltaics

Office of Energy Efficiency \& Renewable Energy. (2016, October 7). SunShot Vision Study. Retrieved from energy.gov: https://energy.gov/eere/sunshot/sunshot-vision-study

Renewable Portfolio Standards. (2015, July 6). Retrieved from National Renewable Energy Laboratory: http://www.nrel.gov/tech_deployment/state_local_governments/basics_portfolio_standards.html

Robin, W. (2016, June 2). Solar industry set for new overcapacity cycle as 2016 outlook deteriorates. Retrieved from Renewable Energy Magazine: https://www.renewableenergymagazine.com/pv_solar/solar-industry-set-for-new-overcapacity-cycle-20160602

Roselund, C. (2015, December 18). Solar ITC extension approved in the U.S. Senate. Retrieved from PV Magazine: https://www.pv-magazine.com/2015/12/18/solar-itc-extension-approved-in-the-u-s-senate_100022519/

Santen, N. R., \& Anadon, L. D. (2016, July). Balancing solar PV deployment and RD\&D: A comprehensive framework for managing innovation uncertainty in electricity technology investment planning. Renewable and Sustainable Energy Reviews, 560-569. https://doi.org/10.1016/j.rser.2015.12.272

SEIA. (2016, November 16). Solar ITC Impact Analysis. Retrieved from Solar Eneregy Industries Association: http://www.seia.org/research-resources/solar-itc-impact-analysis

SEIA. (2016, November 9). Solar Investment Tax Credit (ITC). Retrieved from Solar Energy Industries Association: http://www.seia.org/policy/finance-tax/solar-investment-tax-credit

Solar Energy Industries Association. (2016, February 22). U.S. Solar Market Sets New Record, Installing 7.3 GW of Solar PV in 2015. Retrieved from Solar Energy Industries Association: http://www.seia.org/news/us-solar-market-sets-new-record-installing-73-gw-solar-pv-2015

Solar Energy Industries Association. (2016, October 7). Solar Industry Data. Retrieved from Solar Energy Industries Association: http://www.seia.org/research-resources/solar-industry-data

Song, D., Jiao, H., \& Fan, C. T. (2015, August). Overview of the photovoltaic technology status and perspective in China. Renewable and Sustainable Energy Reviews, 848-856. https://doi.org/10.1016/j.rser.2015.04.001

The Solar Foundation. (2016). National Solar Jobs Census. Retrieved from The Solar Foundation: http://www.thesolarfoundation.org/national/

U.S. Energy Information Administration. (2017). Short-term Energy Outlook June 2017. U.S. Energy Information 
Administration. Retrieved from http://www.eia.gov/forecasts/steo/pdf/steo_full.pdf

United Nations Development Programme. (2016, April 28). 13th Five-Year Plan: What to Expect from China. Retrieved from cn.undp.org:

http://www.cn.undp.org/content/china/en/home/library/south-south-cooperation/13th-five-year-plan--what-to-expe ct-from-china.html

Xie, Y. (2014, July 29). Ministry urges 'prudent' US stance in solar rows. Retrieved from China Daily: http://www.chinadaily.com.cn/business/2014-07/29/content_17945508.htm

Zhang, F., Deng, H., Margolis, R., \& Su, J. (2015, June). Analysis of distributed-generation photovoltaic deployment, installation time and cost, market barriers, and policies in China. Energy Policy, 43-55. https://doi.org/10.1016/j.enpol.2015.02.010

Zhao, X., Zeng, Y., \& Zhao, D. (2015, August). Distributed solar photovoltaics in China: Policies and economic performance. Energy, 572-583. https://doi.org/10.1016/j.energy.2015.05.084

Zhi, Q., Sun, H., Li, Y., Xu, Y., \& Su, J. (2014, September 15). China's solar photovoltaic policy: An analysis based on policy instruments. Applied Energy, 308-391. https://doi.org/10.1016/j.apenergy.2014.05.014

Zhou, E. (2015). U.S. Renewable Energy Policy and Industry. National Renewable Energy Laboratory.

\section{Copyrights}

Copyright for this article is retained by the author(s), with first publication rights granted to the journal.

This is an open-access article distributed under the terms and conditions of the Creative Commons Attribution license which permits unrestricted use, distribution, and reproduction in any medium, provided the original work is properly cited. 